cuống mạch - ghép da (20/25-80\%) và không có kết quả xấu nào trong cả hai thời điểm đánh giá. Kết quả này cho thấy, chỉ định PPPT đóng trực tiếp và vat ngẫu nhiên với các tổn khuyết nhỏ $(<5$ $\left.\mathrm{cm}^{2}\right)$ - trung bình $\left(5-20 \mathrm{~cm}^{2}\right)$ cho kết quả tốt và tương tự với kết quả của các tác giả Cherubino. $M(2013)$, Cleyton.D. Souza (2012) [5,6].

Bên cạnh đó, kết quả trên gợi ý rằng, với các tổn khuyết lớn $\left(>20 \mathrm{~cm}^{2}\right)$, việc sử PPPT kết hợp vạt cuống động mạch thái dương nông hoặc động mạch chẩm và ghép da mang lại kết quả sau phẫu thuật rất khả quan với tỷ lẹ̣ vạt sống cao và kết quả xa tốt lên, cũng như đảm bảo các yêu cầu thẩm mỹ về vùng da có tóc. Bên cạnh đó, kết hợp kết quả này với độ tuổi trung bình tương đối lớn của nhóm đối tượng trong nghiên cứu $(66,33$; +/- 17,85; trẻ tuổi nhất là 31 tuổi, lớn tuổi nhất là 72) đã gợi ý rằng việc áp dụng PPPT kết hợp vạt cuống động mạch thái dương nông hoặc động mạch chẩm và ghép da sẽ phù hợp và giúp đạt kết quả phẫu thuật tốt nhất với tình trạng lâm sàng của nhóm bệnh nhân cao tuổi.

\section{KẾT LUÂNN}

Vùng da đầu có tổn thương hay gặp là vùng đỉnh, đỉnh - chẩm và thái dương, tỷ lệ tổn khuyết vừa và lớn chiếm $72 \%$, có $28 \%$ thâm nhiếm sâu (cốt mạc, xương, màng não).

Kết quả phẫu thuật cho thấynhóm bệnh nhân chỉ định PPPT đóng trực tiếp với các tổn khuyết nhỏ $\left(<5 \mathrm{~cm}^{2}\right)$ và sử dụng vạt da cân ngẫu nhiên với các tổn khuyết trung bình $\left(5-20 \mathrm{~cm}^{2}\right)$ là hoàn toàn phù hợp, đồng thời chỉ định PPPT kết hợp vạt cuống động mạch thái dương nông hoặc động mạch chẩm kết hợp ghép da xẻ đôi che phủ phần cho vạt để che phủ các tổn khuyết lớn $\left(>20 \mathrm{~cm}^{2}\right.$ ) là phương án hữu dụng, an toàn, cho kêt quả tốt nhất là đối với nhóm bênh nhân lớn tuổi có nhiều yếu tố bệnh lý nền, thể trạng sức khoẻ không đảm bảo cho các phương pháp khác như giãn da, vi phẫu.

\section{TÀI LIÊU THAM KHẢO}

1. Nguyễn Bắc Hùng (2017), Bài giảng phâu thuật tạo hình thẩm mỹ.

2. Nguyễn Huy Phan (1999), Lịch sử phát triển kỹ thuât vi phấu thân kinh trên thế giới và ở Viêt Nam.

3. Trân Thiết Sơn (2007), Nhận xét các kết quả tạo hình khuyết lớn da đầu.

4. Archontaki M., et al (2009). Giant Basal Cell Carcinoma: Clinicopathological Analysis of 51 Cases and Review of the Literature. Anticancer Research 29: 2655-2664.

5. Cherubino M., et al. (2013). A New Algorithm for The Surgical Management of Defects of the Scalp. ISRN Plast Surg, 2013, 1-5.

6. Cleyton .D. Souza (2012). Reconstruction of large scalp and forehead defects following tumor resection: personal strategy and experience - analysis of 25 cases. Rev Bras Cir Plást. 2012;27(2):227-37.

7. Keck M, et al (2012). Primary cutaneous adenoid carcinoma of the scalp. GMS Interdiscip Plast Reconstr Surg DGPW. 2012;1:Doc04

8. Onishi K., et al. (2005). Repair of scalp defect using a superficial temporal fascia pedicle $\mathrm{VY}$ advancement scalp flap. Br J Plast Surg, 58 (5), 676-680.

\title{
KHẢO SÁT MỨC Độ HOÀN THIỀN CỦA HÊ THỐNG TỔ CHỨC Y TẾ TRONG QUẢN LÝ MỸ் PHẨM TẠI VIỆT NAM
}

\author{
Hoàng Thy Nhạc Vũ*, Trần Thị Ngọc Vân*, Lê Thị Kiều Oanh*
}

\section{TÓM TẮT}

Mục tiêu: Nghiên cứu nhằm khảo sát mức độ hoàn thiện của hệ thống tổ chức y tế trong quản lý mỹ் phẩm tại Việt Nam. Đối tượng và phương pháp: Nghiên cứu được thực hiện thông qua việc tổng hợp và phân tích nội dung các quy định về quản lý mỹ phâm tại Việt Nam, do cấp trung ương ban hành, có pham vi áp dung toàn quốc, và còn hiệu lực tính đến ngày 01/06/2021. Kết quả: Thông qua khung pháp lý hiện hành về quản lý mỹ phẩm tai Việt Nam, với 36 văn bản liên quan đã được ban hành và còn hiệu lực

*Đại hoc Y Dược TP Hồ Chí Minh

Tác giả liên lạc: Hoàng Thy Nhạc Vũ, Email: hoangthynhacvu@ump.edu.vn Ngày nhận bài: 14/5/2021

Ngày phản biên khoa học: 10/6/2021

Ngày duyệt bài: 9/7/2021
(2 Điều ước quốc tế, 5 văn bản Luât, 10 Nghi đinh, 2 văn bản hợp nhất, 10 Thông tư, và 7 Quyết định), có thể thấy cơ quan y tế đã thực hiện vai trò quản lý trong năm lĩnh vực chính, với 12 văn bản vê xuất khẩu, nhập khẩu mỹ phẩm; 8 văn bản về kiểm nghiệm, kiểm tra đảm bảo chất lượng mỹ phẩm; 7 văn bản về công bố sản phẩm mỹ phẩm; 6 văn bản về quảng cáo mỹ phẩm; và 6 văn bản về sản xuất mỹ phẩm. Văn bản hợp nhất số 07/VBHN-BYT năm 2021 và Quyết định số 7866/QĐ-BYT năm 2018 là những văn bản quan trọng vì liên quan đến nhiều lĩnh vực trong quản lý mỹ phẩm. Kết luân: Thông tin thu được đã cung cấp một bức tranh toàn cảnh về vai trò của cơ quan y tế và mức độ hoàn thiện của hệ thống y tế trong quản lý mỹ phẩm tại Việt Nam trong việc thực hiện các giải pháp của chiển lược quốc gia về bảo vệ, chăm sóc và nâng cao sức khỏe nhân dân.

Tư khóa: Chiến lước quốc gia, hệ thống tổ chức y tễ, quản lý mỹ phẩm, khung pháp lý, Việt Nam. 


\section{SUMMARY \\ SURVEYING THE COMPLETENESS OF THE SYSTEM OF HEALTH ORGANIZATION IN COSMETICS MANAGEMENT IN VIETNAM}

Objectives: This study aimed to survey the completeness of the system of health organizations in managing cosmetic products in Vietnam. Materials and Methods: This study was carried out by summarizing all legal documents of central authorities on cosmetics management still in effect at the national level till 01/06/2021. Results: By viewing the legal framework of the current regulations on cosmetics management with 36 legal documents still in effect (2 International treaties, 5 legal documents, 10 Decrees, 2 Consolidation documents, 10 Circulars, and 7 Decisions), it could be seen that health organizations have played management roles in 5 main management areas, including 12 documents regarding cosmetic exporting or importing, 8 documents regarding the cosmetic quality check; 7 documents regarding cosmetic product proclamation; 6 documents regarding cosmetic advertising, and 6 documents regarding cosmetic manufacture. Circular No. 7/VBHN-BYT issued in 2021 and Decision No. 7866/QĐ-BYT issued in 2018 were the most important documents as they involve many different cosmetic management areas. Conclusions: This study provided an overview of the roles of the system of health organizations and its completeness in implementing solutions of the national strategy to protect, care and improve public health.

Keywords: National strategy, system of health organizations, cosmetics management, legal framework, Vietnam.

\section{I. ĐĂT VẤN ĐỀ}

Tại Việt Nam, cùng với thuốc, mỹ phẩm là một trong những loại hàng hóa đặc biệt, có ảnh hưởng trực tiếp đên sức khỏe của người dân, và chịu sự quản lý trực tiếp của Bộ Y tế. Trong bối cảnh phát triển không ngừng của xã hội, thị trường các sản phẩm phục vụ cho sức khỏe thể chất và tinh thần ngày một đa dạng về chủng loại và chất lượng. Trong chiến lược quốc gia bảo vệ, chăm sóc và nâng cao sức khỏe nhân dân giai đoạn 2011-2020, tầm nhìn đến năm 2030, để thực hiện được mục tiêu bảo đảm mọi người dân được hưởng và sử dụng các dịch vụ y tế có chất lượng, được sống trong cộng đồng an toàn, phát triển tốt về thể chất và tinh thần, một trong những giải pháp được đề ra là hoàn thiện hệ thống tố chức $y$ tế về rất nhiêu sản phẩm liển quan đến sức khỏe của người dân, trong đó có mỹ phẩm. Sự phát triển nhanh chóng của thị trường mỹ phẩm tại Việt Nam đã tạo nên những thách thức nhất định cho cơ quan quản lý trong việc đảm bảo chất lượng của các sản phẩm đang lưu hành trên thị trường. Để tạo điều kiện thuận lợi cho hoạt động quản lý mỹ phẩm tại Việt Nam, cần có một khung pháp lý hoàn chỉnh và phù hợp với bối cảnh thực tiển.

Trong thời gian qua, đã có nhiều quy định được cơ quan quản lý nhà nước xây dựng, ban hành, và áp dụng. Nghiên cứu được thực hiện nhằm khảo sát mức độ hoàn thiện của hệ thống tổ chức y tế trong quản lý mỹ phẩm tại Việt Nam thông qua việc tổng hợp phân tích nội dung các quy định hiện hành trong hoạt động quản lý mỹ phẩm giai đoạn hiện nay, góp phần trong việc đảm bảo chất lượng hàng hóa trong kinh doanh, giúp người tiêu dùng có được những sản phẩm an toàn và chất lượng.

\section{II. ĐỐI TƯợNG VÀ PHƯƠNG PHÁP NGHIÊN CỨU}

2.1. Đối tượng nghiên cứu: Nghiên cứu thực hiện trên các văn bản pháp luật liên quan đển quy định quản lý mỹ phẩm tại Việt Nam.

2.2. Tiêu chuẩn nghiên cứu: Chỉ những văn bản pháp quy cấp trung ương, có phạm vi áp dụng toàn quốc, còn hiệu lực tính đến ngày 01/06/2021, và có nội dung liến quan đến quy định quản lý mỹ phẩm mới được lựa chọn để nghiên cứu và tổng hợp. Nghiên cứu loại ra các văn bản chỉ đao điều hành, bao gồm số lượng lớn là các quyết định phê duyệt kế hoạch hoặc thu hồi mỹ phẩm.

2.3. Tổng hợp và phân tích dữ liệu: Nghiên cứu sử dung từ khóa "mỹ phẩm" để tiên hành tìm kiếm văn bản liên quan đến các quy định về quản lý mỹ phẩm tại Việt Nam trên Trang điện tử Cơ sở dữ liệu quốc gia về văn bản pháp luật (http://vbpl.vn/) và Trang điện tử của Cục Quản lý Dược-Bộ Y tế (https://dav.gov.vn/). Sau khi xem xét tất cả các văn bản pháp luật thỏa tiêu chí đưa vào và tiêu chí loại trừ, nghiên cứu đã chọn được 36 văn bản pháp quy để tiến hành mô tả đặc điểm của khung pháp lý. Nghiên cứu sử dụng phương pháp mô tả định tính, khung pháp lý về quản lý mỹ phẩm sẽ được mô tả theo số lượng, phân cấp quản lý, và nội dung quản lý.

\section{KẾT QUẢ NGHIÊN CỨU}

3.1. Đặc điểm chung hệ thống tổ chức y tế trong quản lý mỹ phẩm. Cơ quan quản lý đã ban hành 36 văn bản pháp luật, thuộc 6 cấp độ pháp lý khác nhau, trong đó có 2 Điều ước quốc tế, 5 văn bản Luật, 10 Nghị định, 2 văn bản hợp nhất, 10 thông tư, và 7 quyết định. Các lĩnh vực được tập trung quản lý thể hiện qua nội dung của 12 văn bản về xuất khẩu, nhập khẩu mỹ phẩm; 8 văn bản về kiểm nghiệm, kiểm tra đảm bảo chất lương mỹ phẩm; 7 văn bản về công bố sản phẩm mỹ phẩm; 6 văn bản về quảng cáo mỹ phẩm; và 6 văn bản về sản xuất 
mỹ phẩm. (Bảng 1)

3.2. Vai trò của hệ thống tổ chức y tế trong từng lĩnh vực quản lý mỹ phẩm Quy định về Công bố sản phẩm mỹ phẩm. Theo quy định, mỹ phẩm muốn được lưu hành tại Việt nam cần phải được cơ quan quản lý cấp Số tiếp nhận Phiếu công bố sản phẩm mỹ phẩm. Thủ tục cấp số tiếp nhận Phiếu công bố sản phẩm mỹ phẩm sản xuất trong nước và mỹ phẩm nhập khẩu được quy định lần lượt ở Quyết định số 7866/QĐ-BYT và Quyết định số 1907/QĐi-BYT. Ngày 02/09/2003, Hiêp định về Hệ thống hòa hợp ASEAN trong quản lý mỹ phẩm được ký kết giữa Việt Nam với 9 quốc gia khác trong khối ASEAN, thống nhất khái niệm và phân loại mỹ phẩm, tạo căn cứ pháp lý cho việc công nhận lẫn nhau. Khái niệm và phân loại mỹ phẩm của Hiệp định trên đã được thống nhất tại Thông tư số 06/2011/TT-BYT do Bộ Trưởng Bộ Y tế ban hành ngày 25/01/2011 (Bảng 2).

Căn cứ pháp lý liên quan Công bố sản phẩm mỹ phẩm tại Việt Nam gồm Thông tư số 06/2011/TT-BYT, Thông tư số 277/2016/TT-BTC, Nghị định số 155/2018/NĐ-CP, Thông tư' số 29/2020/TT-BYT, Quyết định số 7866/QĐ-BYT năm 2018, Văn bản hơp nhất số 07/VBHN-BYT năm 2021, Quyết định số 1907/QĐ-BYT năm 2021.

Quy định về Kiểm tra đảm bảo chất lượng sản phẩm mỹ phẩm. Theo quy định, nhà sản xuất phải đánh giá tính an toàn trên mỗi sản phẩm theo các hướng dẫn đánh giá tính an toàn mỹ phẩm trong Hiệp định về Hệ thống hòa hợp ASEAN trong quản lý mỹ phẩm, để đảm bảo các sản phẩm đó không có hại đối với sức khoẻ con người khi được dùng trong những điêuu kiện được quy định rõ bởi nhà sản xuất hoặc chủ sở hữu sản phẩm. Khi các mỹ phẩm đã được lưu hành, các cơ quan quản lý mỹ phẩm có thể thành lập đoàn kiểm tra, giám sát chất lượng mỹ phẩm để kiểm tra, thanh tra định kì chất lượng của các mỹ phẩm trên địa bàn quản lý; hoặc kiểm tra, thanh tra đột xuất khi phát hiện những sản phẩm không đạt chất lượng, không tuân thủ quy định lưu thông trên thị trường. Nội dung và thời gian kiểm tra, đánh giá việc thực hiện các quy định quản lý nhà nước về mỹ phẩm được quy định ở Quyết định số 4369/QĐ-BYT năm 2019.

Quy định về Quảng cáo mỹ phẩm. Theo quy định, các đơn vị chỉ được phép quảng cáo, tổ chức hội thảo, sự kiện giới thiệu các sản phẩm mỹ phẩm khi có Giấy xác nhận nội dung quảng cáo cấp bởi Sở $Y$ tế. Nội dung quảng cáo mỹ phẩm phải bao gồm đầy đủ các thông tin theo quy định, và không được không được quảng cáo mỹ phẩm gây hiểu nhầm sản phẩm đó là thuốc. Căn cứ pháp lý về Quảng cáo mỹ phẩm gồm Hiệp định về Hệ thống hòa hợp ASEAN trong quản lý mỹ phẩm, Luật Quảng cáo số 16/2012/QH113, Nghị định số 181/2013/NĐ-CP, Văn bản hợp nhất số 603/VBHN-BVHTTDL, Thông tư số 06/2011/TT-BYT, Thông tư số 09/2015/TT-BYT, Thông tư số 29/2020/TT-BYT, Văn bản hợp nhất số 07/VBHN-BYT năm 2021.

Quy định về Sản xuất mỹ phẩm. Tất cả các cơ sở sản xuất mỹ phẩm trong nước phải được Sở $Y$ tế cấp Giấy chứng nhân đủ điều kiên sản xuất mỹ phẩm trên cơ sở đủ điện kiện về nhân sự, cơ sở vật chất và hệ thống quản lý chất lượng trước khi bắt đầu sản xuất. Đối hoạt động sản xuất mỹ phẩm để xuất khẩu, các cơ sở này phải được Cục Quản lý Dược cấp Giấy chứng nhận cơ sở đáp ứng các nguyên tắc, tiêu chuẩn "Thực hành tốt sản xuất mỹ phẩm" của Hiệp hội các nước Đông Nam Á (CGMP-ASEAN). Nội dung cụ thể được quy định trong Quyết định số 24/2006/QĐ-BYT, Nghị định số 93/2016/NĐ-CP, Thông tư số 277/2016/TT-BTC, Nghi đinh số 155/2018/ND-CP, và Quyết định số 7866/QĐBYT năm 2018.

Quy định về Xuất khẩu, nhập khẩu mỹ phẩm. Những quy định về xuất khẩu mỹ phẩm phải dựa trên sự đồng thuận trong Hiệp định về Hệ thống hòa hợp ASEAN trong quản lý mỹ phẩm và quy định của mỗi quốc gia. Khi nhập khẩu mỹ phẩm vào Viêt Nam, đơn vị kinh doanh mỹ phẩm phải xuất trình Giấy chứng nhân lưu hành tự do (Certificate of Free Sale - CFS) hợp lệ với cơ quan Hải quan khi làm thủ tục nhập khẩu. Ngoài ra, mỹ phẩm nhập khẩu cần phải đáp ứng đầy đủ các quy định về nhãn của Bô $Y$ tế và theo quy định về nhãn hàng hóa của Chính phủ (Nghị định số 43/2017/NĐ-CP). Đối với mỹ phẩm sản xuất trong nước có nhu cầu xuất khẩu, Bộ $Y$ tế đã ban hành các căn cứ pháp lý (Văn bản hợp nhất số 07/VBHN-BYT năm 2021, Quyết định số 1907/QĐ-BYT năm 2021 để hướng dẫn cấp Giấy chứng nhận lưu hành tự do (Certificate of Free Sale - CFS) cho các cơ sở sản xuất.

Quy định khác: Các tổ chức, cá nhân thực hiện công việc liên quan đến lĩnh vực dược, mỹ phẩm với Biểu phí ban hành theo quy định kèm theo Thông tư số 277/2016/TT-BTC ngày 14/11/2016. Nội dung quy định xử phạt vi phạm hành chính trong lĩnh vực quảng cáo mỹ phẩm được quy định trong cụ thể trong Nghị định số 38/2021/ND-CP và các lính vực khác liên quan đến mỹ phẩm trong Nghị định số 117/2020/NĐ-CP. 
Bảng 1. Hê thống tổ chức y tế về quản lý mỹ phẩm tại Việt Nam theo cấp độ pháp lý và các lĩnh vực quản lý chính (các văn bản còn hiệu lực tính đến 01/06/2021)

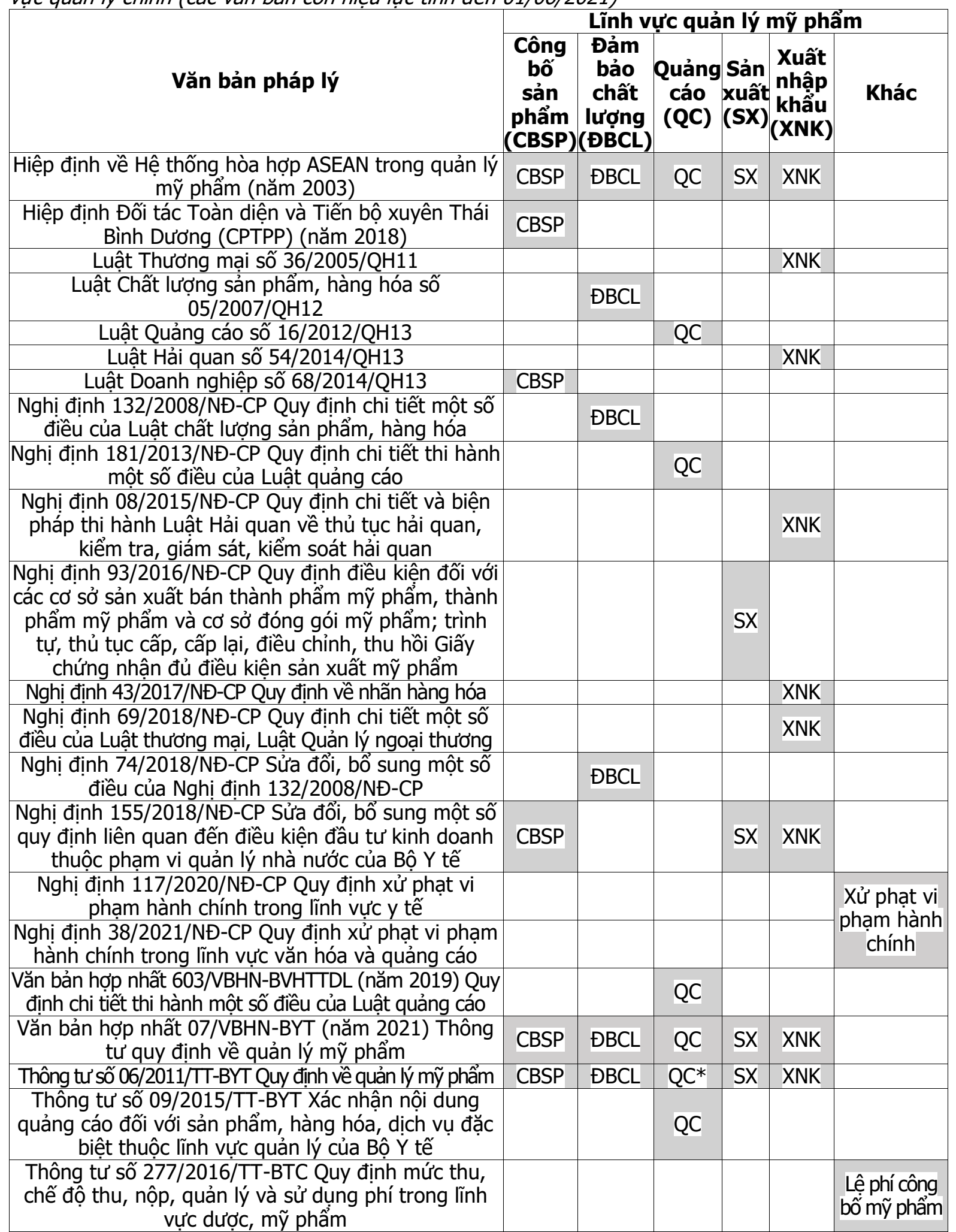




\begin{tabular}{|c|c|c|c|c|c|c|}
\hline \multicolumn{2}{|c|}{$\begin{array}{c}\text { Thông tư số 45/2016/TT-BYT Ban hành danh mục } \\
\text { thuốc dùng cho người và mỹ phẩm nhâap khẩu và̀o } \\
\text { Việt Nam đã được xác định mã số hàng hóa theo } \\
\text { danh mục hàng hóa xuất khẩu, nhâap khẩu và Biểu } \\
\text { thuế nhập khẩu ưu đẩi }\end{array}$} & & & & XNK & \\
\hline \multicolumn{2}{|c|}{$\begin{array}{l}\text { Thông tư số 114/2017/TT-BTC Sửa đối Biểu mức thu phí } \\
\text { trong lính vực dược, mỹ phẩm kèm theo Thông tư số } \\
\text { 277/2016/Tí-BTC quy định mức thu, chế độ thu, nộp, } \\
\text { quản lý và sử dụng phí trong lính vực dược, mỹ phẩm }\end{array}$} & & & & & $\begin{array}{l}\text { Lệ phí } \\
\text { quảng cáo } \\
\text { mỹ phẩm }\end{array}$ \\
\hline \multicolumn{2}{|c|}{$\begin{array}{l}\text { Thông tư số 65/2017/TT-BTC Ban hành danh mục } \\
\text { hàng hóa xuất khẩu, nhập khẩu Việt Nam }\end{array}$} & & & & XNK & \\
\hline \multicolumn{2}{|c|}{$\begin{array}{c}\text { Thông tư số 06/2018/TT-BYT Ban hành danh mục thuốc, } \\
\text { nguyên liệu làm thuốc dùng cho người và mỹ phẩm xuất } \\
\text { khẩu, nhập khẩu đã đước xác định mã số hàng hóa theo } \\
\text { danh mục hàng hóa xuất khẩu, nhập khẩu VN }\end{array}$} & & & & XNK & \\
\hline \multicolumn{2}{|c|}{$\begin{array}{c}\text { Thông tư số 09/2019/TT-BTC Sứa đổi, bố sung một } \\
\text { số nội dung tại các phụ lục của Thông tư số số } \\
\text { 65/2017/TT-BTC Ban hành danh mục hàng hóa xuất } \\
\text { khẩu, nhập khẩu Việt Nam } \\
\end{array}$} & & & & XNK & \\
\hline \multicolumn{2}{|c|}{$\begin{array}{c}\text { Thông tư số 06/2020/TT-BYT Quy định hệ thống chỉ } \\
\text { tiêu thống kê Dược-mỹ phẩm }\end{array}$} & & & & & $\begin{array}{l}\text { Chỉ tiêu thốn } \\
\text { kê mỹ phẩm }\end{array}$ \\
\hline \multicolumn{2}{|c|}{$\begin{array}{l}\text { Thông tư số 29/2020/TT-BYT Sửa đối, bố sung và } \\
\text { bãi bỏ một số văn bản quy pham pháp luật do bộ } \\
\text { trưởng bộ y tế ban hành, liển tịch ban hành }\end{array}$} & CBSP & & & & \\
\hline \multicolumn{2}{|c|}{$\begin{array}{l}\text { Quyết định số 2585/QĐ-BYT (năm 1996) Giao nhiệm } \\
\text { vụ kiểm nghiệm, xác định chất lượng mỹ phẩm ảnh } \\
\text { hưởng trực tiếp đến sức khoẻ con người }\end{array}$} & & $Đ B C L$ & & & \\
\hline \multicolumn{2}{|c|}{$\begin{array}{c}\text { Quyết định số 24/2006/QĐ-BYT Triến khai áp dụng } \\
\text { và hướng dẫn thực hiện các nguyên tắc, tiêu chuẩn } \\
\text { "Thực hành tốt sản xuất mỹ phẩm" của Hiệp hội các } \\
\text { nước Đông Nam Á }\end{array}$} & & & SX & & \\
\hline \multicolumn{2}{|c|}{$\begin{array}{c}\text { Quyết định số 4265/QĐ-BYT (năm 2009) Ban hành } \\
\text { quy trình thanh tra mỹ phẩm }\end{array}$} & & ĐBCL & & & \\
\hline \multicolumn{2}{|c|}{$\begin{array}{c}\text { Quyết định số 4708/QĐ-BYT (năm 2016) Công bố } \\
\text { thủ tực hành chính mới tại Nghị định số 93/2016/NĐ- } \\
\text { CP quy định về điều kiện sản suất mỹ phẩm }\end{array}$} & & & SX & & \\
\hline \multicolumn{2}{|c|}{$\begin{array}{c}\text { Quyết định số 7866/QĐ-BYT (năm 2018) Công bố } \\
\text { thủ tực hành chính mới ban hành, được sửa đổi, bổ } \\
\text { sung trong lĩnh vực mỹ phẩm thuộc phạm vi chức } \\
\text { năng quản lý của Bộ Y Y tế }\end{array}$} & CBSP & ĐBCL & SX & XNK & \\
\hline \multicolumn{2}{|c|}{$\begin{array}{l}\text { Quyết định số 4369/QĐ-BYT (năm 2019) Ban hành } \\
\text { nội dung và thời gian kiểm tra, đánh giá việc thực hiện } \\
\text { các quy định quản lý nhà nước về dược, mỹ phẩm }\end{array}$} & & $Đ B C L$ & & & \\
\hline \multicolumn{2}{|c|}{$\begin{array}{c}\text { Quyêt định số 1907/QĐ-BYT (năm 2021) Công bố } \\
\text { thủ tục hành chính mới ban hành/sửa đổi, bổ sung } \\
\text { trong lĩnh vực mỹ phẩm thuộc phâm vi chức năng } \\
\text { quản lý của Bộ Y tế }\end{array}$} & CBSP & & & & \\
\hline \multicolumn{7}{|c|}{$\begin{array}{l}\text { *Các hướng dấn về quảng cáo mỹ phẩm của Thông tư số 06/2011/TT-BYT đã hết hiệu lực và } \\
\text { được thay thế bằng các hướng dẫn trong Thông tư số 09/2015/TT-BYT. } \\
\text { Bảng 2. Phân loại mỹ phẩm theo Hiệp định về Hệ thống hòa hợp ASEAN trong quản lý mỹ phẩm } \\
\text { và Thông tư số 06/2011/TT-BYT }\end{array}$} \\
\hline \multicolumn{4}{|l|}{$\begin{array}{l}\text { va Thong tư so 06/2011, } \\
\text { Khái niêm mỹ phẩm }\end{array}$} & & & \\
\hline $\begin{array}{l}\text { Sản phấm được sử } \\
\text { dụng để tiếp xúc với }\end{array}$ & $\begin{array}{l}\text { (1) kem, nhũ tương, sữa, gel, } \\
\text { (2) mặt nạ (chỉ trừ sản phẩm }\end{array}$ & $\begin{array}{l}\text { hoặc d } \\
\text { làm bol }\end{array}$ & $\begin{array}{l}\text { u dùn } \\
\text { g da r }\end{array}$ & & & \\
\hline
\end{tabular}




\begin{tabular}{|c|c|}
\hline 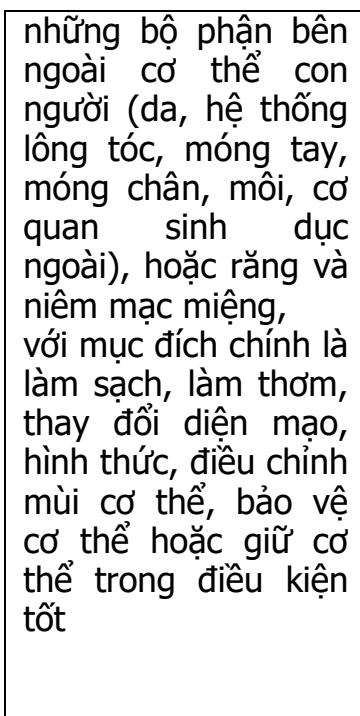 & 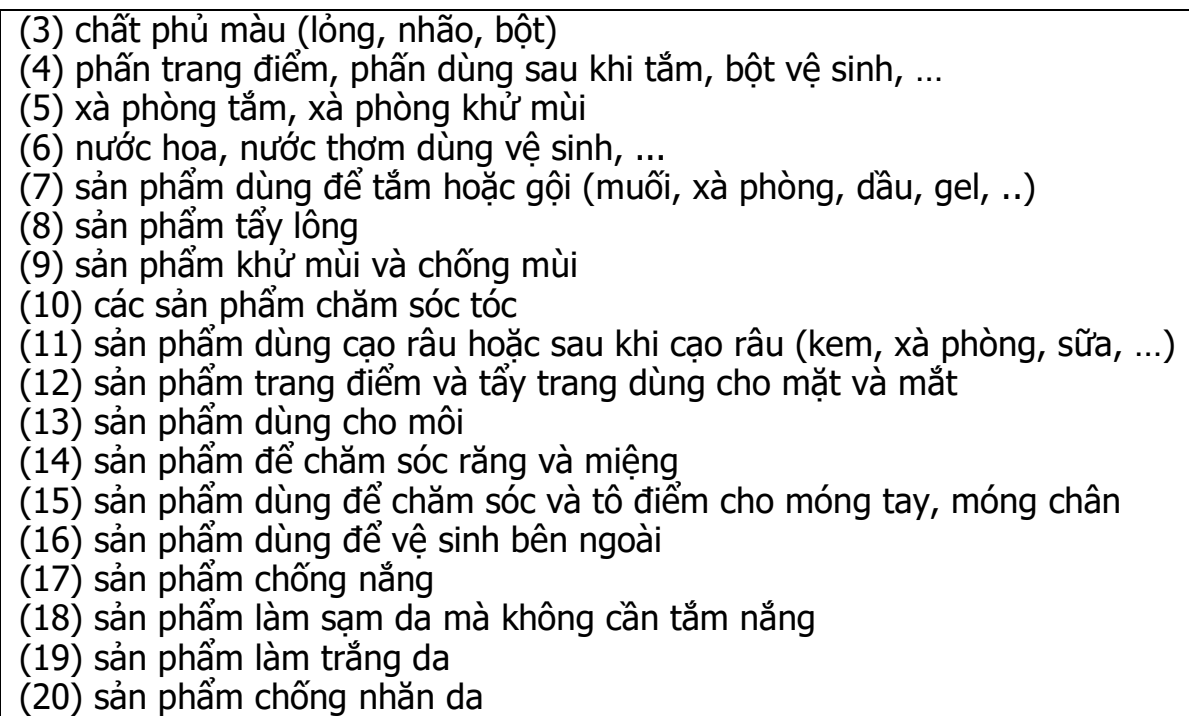 \\
\hline
\end{tabular}

\section{BÀN LUÂN}

Nghiên cứu đã cho thấy trong hoat động quản lý mỹ phẩm, việc cơ quan quản lý ký kết Hiệp định về Hệ thống hòa hợp ASEAN trong quản lý mỹ phẩm năm 2003(1) đã đánh dấu mốc quan trọng trong hội nhập quốc tế trong quản lý mỹ phẩm. Những nội dung đồng thuận tại Hiệp định đã và đang là căn cứ để cơ quan quản lý về y tế Việt Nam và các nước thành viên xây dựng, ban hành, sửa đổi, bổ sung các quy định hiện hành, đảm bảo hoạt động quản lý phù hợp với quy ước quốc tế.

Với tình hình số lượng và chủng loại mỹ phẩm đang gia tăng nhanh trên thị trường Việt Nam, cơ quan quản lý về y tế đã xây dựng, ban hành, và áp dụng rất nhiều văn bản pháp lý về quản lý mỹ phẩm trong thời gian qua. Mặc dù đều chịu sự quản lý trực tiếp của Bộ Y tế, việc quản lý mỹ phẩm ít nghiêm ngặt hơn so với thuốc. Khung pháp lý về quản lý mỹ phẩm hiện nay cơ bản đã hoàn chỉnh, với các văn bản pháp luật khi ban hành đều áp dụng chung cho các nhóm mỹ phẩm ${ }^{(2-3)}$. Để đạt yêu cầu chất lượng của sản phẩm mỹ phẩm thì một nhà máy sản xuất trong nước chỉ cân đạt tiêu chuẩn chất lượng GMP của Bộ $Y$ tế hoặc CGMP-ASEAN( ${ }^{(4)}$. Theo một nghiên cứu tại Thành phố Hồ Chí Minh ${ }^{(5)}$, sau khi Nghi định số 93/2016/NĐ-CP quy định về điều kiên sản xuất mỹ phẩm được ban hành, các cơ sở sản xuất mỹ phẩm bắt buộc phải được tiền kiểm về điều kiện sản xuất trước khi tiến hành sản xuất, số lượng Số tiếp nhận Phiếu công bố mỹ phẩm được Sở $Y$ tế Thành phố Hồ Chí Minh cấp đã giảm đáng kể so với giai đoạn trước đó, cho thấy hiêu quả bước đầu của cồng tác quản lý mỹ phẩm theo hướng ngày càng được chặt chẽ hơn, đảm bảo chất lượng của các sản phẩm sản xuất trong nước khi lưu hành trên thị trường. Mặc dù mỹ phẩm có rất nhiều loại, các đơn vị kinh doanh chỉ tập trung đầu tư vào một số nhóm nhất định dựa vào nhu cầu thực tế của thị trường. Theo kết quả của một nghiên cứu tại Viêt Nam trong giai đoạn 2014-2015, nhóm mỹ phẩm dành cho da và nhóm mỹ phẩm có tính năng chăm sóc cơ thể đã có số lượng mỹ phẩm đăng ký kinh doanh và sản xuất vượt trội so với các nhóm mỹ phẩm còn lại (5-6).

Với đặc thù phần lớn mỹ phẩm lưu hành tại Việt Nam là nhập khẩu(5-6), nhiều văn bản pháp luật hiện nay có nội dung tập trung vào quản lý lĩnh vực xuất khẩu, nhập khẩu (với 13 văn bản trong tổng số 36 văn bản hiện hành). Trong các văn bản được ban hành, Quyết địh số 7866/QĐ-BYT ban hành năm 2018(7) và Văn bản hợp nhất số 07/VBHN-BYT ban hành năm 2021(3) là những văn bản quan trọng vì liên quan đến nhiều lĩnh vực trong quản lý mỹ phẩm.

\section{KẾT LUẬN}

Kết quả nghiên cứu đã làm rõ vai trò của cơ quan quan lý trong việc hoàn thiện hệ thống tôn chức y tế, tập trung vào sản phẩm mỹ phẩm, góp phần đạt mục tiêu chung về chăm sóc sức khỏe thể chất và tinh thần cho nhân dân theo chiến lược quốc gia bảo vệ, chăm sóc và nâng cao sức khỏe nhân dân. Ngoài ra, kết quả của nghiên cứu có thể hỗ trợ các cơ quan quản lý trong việc tập trung đánh giá tính đồng bộ và tính phù hợp của các văn bản quản lý mỹ phẩm đã ban hành, làm cơ sở cho việc ban hành các qưy định quản lý chặt chẽ hơn và có tính thực tiễn cao hơn trong tương lai. 
TÀI LIỆ THAM KHẢO

1. Hiệp hội ASEAN (2003). Hiệp định về Hệ thống hòa hợp ASEAN trong quản lý mỹ phẩm, Bản dịch của Cục Quản lý Dược, 2008.

2. Bộ Y tế (2011). Thông tư số 06/2011/TT-BYT Qưy định vê quản lý mỹ phẩm.

3. Bộ y tế (2021). Văn bản hợp nhất số $07 / \mathrm{VBHN}$ BỲ̛T Thông tư quy định về quản lý mỹ phẩm.

4. Chính phủ (2016). Nghi định số 93/2016/NĐ-CP Quy định điêuu kiện đối với các cơ sở sản xuất bán thành phẩm mỹ phẩm, thành phẩm mỹ phẩm và cơ sở đóng gói mỹ phẩm; trình tự, thủ tực cấp, cấp lai, điều chính, thu hồi Giấy chưưng nhận đư điêu kiện sản xuất mỹ phẩm.
5. Hoàng Thy Nhạc Vũ (2017). Thực trạng công tác cấp Số tiếp nhân Phiếu công bố mỹ phẩm của Sở $Y$ tế thành phố Hồ Chí Minh trong giai đoạn 2015-2016. Tạp chí Dược học, 496:66-70.

6. Hoàng Thy Nhạc vĩu, Trân Thị Ngoc Vân, Phạm Vĩnh Thăng (2016). Khảo sát đặc điểm các mỹ phẩm đăng ký quảng cáo tại thành phố Hồ Chí Minh giai đoạn 2014-2015. Tạp chí Y học Thực hành, 1027:6-9.

7. Bô Y tế (2018). Quyết đinh số 7866/QĐ-BYT Cổng bố thư tục hành chính mới ban hành, được sửa đổi, bổ sung trong lĩnh vực mỹ phẩm thuộc phạm vi chức năng quản lý của Bộ Y tê.

\title{
KẾT QUẢ PHẪU THUÂT GIẢI CHÈN ÉP ỐNG SỐNG QUA ỐNG BANH ĐIỀU TRI HẸP ỐNG SỐNG THẮT LƯNG DO THOÁI HÓA
}

\author{
Vi Trường Sơn*, Nguyễn Văn Sơn*, Phan Trọng Hậu**
}

\section{TÓM TẮT}

Mục tiêu: Đánh giá kết quả phẫu thuât giải phóng chèn ép qua ống banh điều trị hẹp ống sổng thắt lưng (HOSTL) do thoái hóa. Đối tượng và phương pháp: Nghiên cứu tiến cứu 62 bệnh nhân (BN) được chẩn đoán HOSTL do thoái hóa được phẫu thuật (PT) giải chèn ép ống sống qua ống banh thuật tại khoa $\mathrm{CTCH}$ côt sống - BVTWQĐ108 từ tháng 3/2015- 09/2016. Kết quả: $62 \mathrm{BN}$ (25 nam, 37 nữ), tuổi trung bình là $57,61 \pm 9,6$ (từ 32 tới 81 ) đã đước PT mở của sổ xương một bên giải chèn ép hai bển qua ống banh. Thời gian giải phóng chèn ép trung bình cho 1 mức đốt sống là $65,00 \pm 10,97$ phút, 02 mức là $85,88 \pm$ 18,04 phút. Kết quả xa sau PT được đánh giá theo thang điểm JOA (Japanese Orthopaedic Association score) tại thời điểm khám lại cuối cùng sau mổ trên 12 tháng 58/62 BN khám $(93,5 \%)$ Thời gian kiểm tra trung bình: $33,47 \pm 16,89$ tháng (12-60). Rất tốt: 22 (37,9\%), tốt: $31(53,4 \%)$, trung bình: $3(5,1 \%)$, kém: 2 (3,6\%). Đánh giá cải thiện triệu chứng lâm sàng sau can thiệp tại thời điểm khám cuối cùng: điểm đau lưng VAS (Visual Analogue Scale) trước mổ 5,03 $\pm 1,24$ khi khám lai là $0,67 \pm 1,09$, điểm đau chân VAS trước mổ là 7,23 $\pm 0,98$ khi khám lại là $0,95 \pm 1,42$, ODI (Oswestry Disability Index 2.0) trước mổ 66,32 $\pm 5,39$ khi khám lại là $17,47 \pm 11,77$, điểm JOA trước phẩu thuật là $11,29 \pm 1,35$ khi khám lại là $24,39 \pm 2,70$. Đánh giá sự gia tăng kích thước của ống sống trên phim công hưởng từ (CHT) sau PT giải chèn ép tai thời điểm khám cuối cùng 35/62 BN với sự thay đổi có ý nghĩa thống kê ( $p<0,001)$ : đường kính trước sau ống sống (ĐKTS) là 4,82 $\pm 1,65$ mm (trước PT:

*Bệnh viện Đa khoa Phú Tho

**Bệnh viện TƯQĐ108

Chịu trách nhiệm chính: Vi Trường Sơn

Email: sonha.tpviettri@gmail.com

Ngày nhận bài: $28 / 5 / 2021$

Ngày phản bienj khoa học: 20/6/2021

Ngày duyệt bài: 19/7/2021
$6,43 \pm 1,34 \mathrm{~mm}$, sau PT:11,25 $\pm 1,59 \mathrm{~mm}$ ) và diện tích ống sống (DTOS) 73,06 $\pm 18,80$ mm² (trước PT: $49,29 \pm 15,09$, sau PT: $122,35 \pm 25,79)$. Biến chứng trong mổ: rách màng cứng: $02(3,2 \%)$, tụ máu ngoài màng cứng $01(1,6 \%)$. Kết luận: Phẫu thuật giải chèn ép ống sống qua ống banh dưới kính vi phẫu thuật là phương pháp can thiệp ít xâm lấn, hiệu quả và an toàn trong điêu trị bệnh lý HOSTL do thoái hóa.

Tư khóa: Hẹp ống sống do thoái hóa, phẫu thuật can thiệp tối thiểu

\section{SUMMARY \\ THE EVALUATION OF UNILATERAL APPROACH FOR BILATERAL DECOMPRESSION OF DEGENNERATIVE LUMBAR SPINAL STENOSIS WITH TUBULAR RETRACTOR SYSTEM}

Aims: To assess the results of minimally invasive surgery approach for degenerative lumbar spinal stenosis. Methods: From 03/2015 to 09/2016 the surgery was performed on 62 patients ( 25 men and 37 women; 32-81years; median age, 57,61 $\pm 9,6$ years). We carried out bilateral interlaminar fenestration and unroofing for the decompression of nerve roots by using a unilateral approach. Result: Average of surgical time was $65,00 \pm 10,97$ minutes for per level, $85,88 \pm 18,05$ minutes for two levels. Surgical results were classified by JOA score at the last follow up, $58 / 62$ patients, average time 33,47 $\pm 16,89$ months. Excellent: $22(37,9 \%)$, good: $31(53,4 \%)$, fair: 3 $(5,1 \%)$, poor: $2(3,6 \%)$. VAS back pain improved from $5,03 \pm 1,24$ to $0,67 \pm 1,09$, VAS radicular pain improved from $7,23 \pm 0,98$ to $0,95 \pm 1,42$, ODI improved from $66,32 \pm 5,39$ to $17,47 \pm 11,77$, JOA improved from $11,29 \pm 1$ to $24,39 \pm 2,70$. The increasing of spinal canal on MRI at the last follow up (35/62 patients) significant difference $(p<0,001)$ : A$P$ diameter: 4,82 $\pm 1,65 \mathrm{~mm}$ (pre-op: 6,43 \pm 1.34 $\mathrm{mm}$; post-op: $11,25 \pm 1,59 \mathrm{mmm})$; Dural sac crosssectional area: 73,06 $\pm 18,80 \mathrm{~mm}^{2}$ (pre-op:49,29 \pm 15,09, post-op: $122,35 \pm 25,79)$. Complications: dural tear were $2(3,2 \%)$ and epidural hematoma in 